\title{
Assessment of Vitamin D Status in Egyptian Children with Type-1 Diabetes Mellitus
}

\author{
Gamal Taha Soliman', Basma Abdelmoez Ali ${ }^{*}$, Ashraf Abdelfadeil Mohamed', Ahmed Mohamed Mahmoud² and Ahmed Abdelaziz Abdellatif
}

${ }^{1}$ Pediatric Department, Faculty of Medicine, Minia University, Egypt

${ }^{2}$ Biochemistry Department, Faculty of Medicine, Minia University, Egypt

\begin{abstract}
Vitamin $D$ and its active form are potent immune-modulators and are known to play an important role in the glucose/insulin metabolism. Studies on type 2 diabetes mellitus (T2DM) have shown that vitamin D increases insulin efficacy; However, there are no studies that define a similar relationship in type 1 diabetes mellitus (T1DM).

Aim of the work: To evaluate serum vitamin $D$ status in children with type 1 diabetes mellitus with comparison to healthy subjects and to correlate its level with different clinical and laboratory parameters.

Subjects and methods: This study included two groups; Group I: included 53 patients with T1D; 43 patients with poor glycemic control (group la ) and 10 patients with good glycemic control (group lb). Another 15 apparently healthy children and adolescent's age and sex matched to the diseased group were taken as a control group and classified as group II. The studied groups were subjected to thorough history taking, clinical examination and laboratory investigations including: fasting blood glucose, glycated hemoglobin ( $\mathrm{HbA} 1 \mathrm{c} \%$ ), serum calcium level and 25 -hydroxyvitD level. A serum $25 \mathrm{OHD}$ level of $<10 \mathrm{ng} / \mathrm{mL}$ was accepted as vitamin D deficiency, whereas $<20 \mathrm{ng} /$ $\mathrm{mL}$ was accepted as vitamin $\mathrm{D}$ insufficiency.

Results: Serum 25-hydroxyvitD and serum calcium levels were significantly lower in T1D children than the control and in group la than group lb. 25-hydroxyvitD had a significant strong positive correlation with serum calcium and significant strong negative correlations with fasting blood sugar and $\mathrm{HbA} 1 \mathrm{c} \%$.

Conclusion: T1D children had significantly lower serum 25- hydroxyl vit $D$ and serum calcium levels than the control group. Vitamin $\mathrm{D}$ in diabetic persons is an important factor in glycemic control with subsequent prevention of further complications.
\end{abstract}

\section{Keywords: T1D; Vitamin D; Hemoglobin A1C}

\section{Introduction}

T1D is an autoimmune disease, in which Beta cells of the pancreas are destructed resulting in a harmful state of hyperglycemia. One of the important factors that recent studies suggested that vitamin D deficiency has a role in the development of this disease. Vitamin $\mathrm{D}$ insufficiency is a risk factor for autoimmune diseases and other disorders. Although optimal supplement dosing with regard to immune and Beta cells function is not known. Vitamin D and its active form are potent immune-modulators and are known to play an important role in the glucose/insulin metabolism. Studies on T2DM have shown that vitamin $\mathrm{D}$ increases insulin efficacy; however, there are no studies that define a similar relationship in T1DM [1].

\section{Aim of the work}

To evaluate serum vitamin $\mathrm{D}$ status in children with type 1 diabetes mellitus with comparison to healthy subjects and to correlate its level with different clinical and laboratory parameters.

\section{Subjects and methods}

This study included 68 child and adolescent who were classified into two groups;

Group I: 53 patients who had already been diagnosed as diabetic patients according to the standard ADA criteria [2] and had regular follow up in pediatric endocrinology outpatients' clinic, Minia university children's hospital, Egypt and Group II: 15 apparently healthy subjects, age and sex matched to the diseased group. They were collected during the period from September 2012 to March 2013.
According to diabetic control and HbAlc \% level, we divided the diabetic group into; group Ia (good controlled): they were 10 patients, their ages ranged between 7 and 18 years, 5 were males (50\%), and 5 were females (50\%), and their HbAlc level was up to $7 \%$ and Group $\mathrm{Ib}$ (poor controlled): 43 patients, their ages ranged between 6 and 17 years, 21 were males ( $48.8 \%)$, and 22 were females (51.2\%), and their HbAlc level was more than $7 \%$. The studied groups were subjected to the following: thorough history taking, clinical examination and laboratory investigations including: random blood glucose levels: (Colorimetric, Human, Germany):Assayed by using fully automated clinical chemistry auto-analyzer system Konelab 20i (Thermo Electron Incorporation, Finland) [2], $\mathrm{HbAlc} \%$ as a parameter for glycemic control by using resin column chromatography. Kit contents were supplied by TECO DIAGNOSTICS, California; USA [3], Calcium Assessment (Colorimetric Method): with normal range of serum calcium in children:10-11.5 mg/dl [4], serum vitamin $\mathrm{D}(25-\mathrm{OH}$ Vitamin D) determination by Immun-diagnostik Enzyme-ImmunoAssay (EIA) [5,6]. With normal range of 25-OH Vitamin D: 25-125

*Corresponding author: Basma Abdelmoez Ali, Professor of pediatrics, Faculty of Medicine, Minia University, Egypt, Tel: 0020100 6227847; 002 0862352728; E-mail: basmaelmoez@yahoo.com

Received May 20, 2015; Accepted June 22, 2015; Published June 26, 2015

Citation: Soliman GT, Ali BA, Mohamed AA, Mahmoud AM, Abdellatif AA (2015) Assessment of Vitamin D Status in Egyptian Children with Type-1 Diabetes Mellitus. J Diabetes Metab 6: 573. doi:10.4172/2155-6156.1000573

Copyright: (c) 2015 Soliman GT, et al. This is an open-access article distributed under the terms of the Creative Commons Attribution License, which permits unrestricted use, distribution, and reproduction in any medium, provided the original author and source are credited. 
Page 2 of 5

nmol/l. Classification of Vitamin D Status by $25(\mathrm{OH}) \mathrm{D}$ concentration [7]: $\leq 25 \mathrm{nmol} / \mathrm{l}$ (Deficient), $>25$ till $50 \mathrm{nmol} / \mathrm{l}$ (Insufficient)and $>50$ $\mathrm{nmol} / \mathrm{l}$ (Optimal).

\section{Statistical Methods [8]}

The data were coded and verified prior to data entry. All statistical analyses were carried out using the Statistical Package for Social Sciences (SPSS/Windows Version 19.0.0, SPSS Inc., an IBM Company). Microsoft excel 2013 was used for drawing figures. Continuous variables were presented as mean followed by standard deviation (SD), and categorical variables were presented as frequency and percentage. For qualitative data: Chi-square (X2) was used: For quantitative data: Independent-Samples T test (for two groups) used in person correlation for correlation between two quantitative variables, Two-tailed partial correlation coefficients ( $r$ ) adjusted for age, sex and BMI was used to assess the relationships between 25-hydroxy vitD and other variables. $\mathrm{P}$-value $<0.001$ (significant)and P-value $>0.001$ (insignificant). Kendl's test: was used for correlation between quantitative and qualitative variables.

\section{Results}

Concerning clinical data, the diabetic children had significantly higher weight and lower height than the control group where $(\mathrm{P}<0.001)$ for both. On contrary, there were insignificant differences between them as regards $\mathrm{BMI}$ and waist circumference where $(\mathrm{P}=0.4)$ and $(\mathrm{P}=0.3)$ respectively (Tables 1 and 2$)$ showed that diabetic children had significantly higher fasting blood sugar, $\mathrm{HbAlc} \%$ and lower serum calcium and 25-hydroxyvitamin D than the control group where $\mathrm{P}<0.001$ for all. Concerning 25 -hydroxyvitD levels in diabetic patients, the current study found that $15.1 \%$ of the studied diabetic group had deficient 25 -hydroxyvitD levels while $84.9 \%$ had insufficient 25-hydroxyvitD levels (N.B: Deficient $\leq 25 \mathrm{nmol} / \mathrm{l}$, Insufficient $>25$ till $50 \mathrm{nmol} / \mathrm{l}$ (Figure 1). Regarding the glycemic control, the current study found that good glycemic controlled diabetic children had significantly lower fasting blood sugar and higher 25-hydroxyvitaminD levels than the poor glycemic controlled diabetic children where $\mathrm{P}<0.001$ (Table 3 ). On contrary, there were insignificant differences between them as regard age, duration of DM, dose of insulin, type of feeding, family history of DM and serum calcium levels. Figure 2 showed that 3 patients with good glycemic controlled had deficient 25 -hydroxyvitD versus 42 patients with poor glycemic controlled while 7 patients with good glycemic controlled had insufficient levels versus one patient with poor glycemic controlled. Concerning different correlations, Table 4 showed

\begin{tabular}{|c|c|c|c|}
\hline Clinical Parameter & $\begin{array}{c}\text { Group I } \\
\text { (Diabetic children) } \\
(\mathrm{N}=53)\end{array}$ & $\begin{array}{c}\text { Group II } \\
\text { (Control) } \\
(\mathrm{N}=15)\end{array}$ & P-Value \\
\hline $\begin{array}{l}\text { Age:(year) } \\
.6-12 \text { years. No }(\%) \\
.12-18 \text { years. No(\%) }\end{array}$ & $\begin{array}{l}17(32.1 \%) \\
36(67.9 \%)\end{array}$ & $\begin{array}{c}5(33.3 \%) \\
10(66.6 \%)\end{array}$ & 0.6 \\
\hline $\begin{array}{l}\text { Sex: } \\
\text { Male. No (\%) } \\
\text { Female. No (\%) }\end{array}$ & $\begin{array}{l}27(51 \%) \\
26(49 \%)\end{array}$ & $\begin{array}{l}10(66.6 \%) \\
5(33.4 \%)\end{array}$ & 0.5 \\
\hline Weight (kg) (Mean \pm SD) & $40.4 \pm 16.2$ & $37.9 \quad 12.6$ & $<0.001^{*}$ \\
\hline Height (cm) (Mean \pm SD) & $142.8 \pm 21.1$ & $149.3 \pm 13.1$ & $<0.001^{*}$ \\
\hline BMI $\left(\mathrm{kg} / \mathrm{m}^{2}\right)($ Mean $\pm S D)$ & $18.9 \pm 4.3$ & $16.8 \pm 2.7$ & 0.4 \\
\hline $\begin{array}{l}\text { Waist circumference }(\mathrm{cm}) \\
\text { (Mean } \pm S D)\end{array}$ & $65 \pm 10.9$ & $68.1 \pm 8.4$ & 0.3 \\
\hline
\end{tabular}

Table 1: Comparison between the diabetic children and controls as regard some clinical parameters.

\begin{tabular}{|l|c|c|c|}
\hline Laboratory parameter & $\begin{array}{c}\text { Group I } \\
\text { No=53 } \\
\text { (Mean } \pm \text { SD) }\end{array}$ & $\begin{array}{c}\text { Group II } \\
\text { No=15 } \\
\text { (Mean } \pm \text { SD) }\end{array}$ & P-Value \\
\hline Fasting blood sugar(mg/dl) & $229.5 \pm 92.6$ & $92.8 \pm 7.6$ & $<0.001^{*}$ \\
\hline HbA1c (\%) & $8.7 \pm 1.8$ & $5.7 \pm 0.6$ & $<0.001^{*}$ \\
\hline Serum calcium(mg/dl) & $8.7 \pm 0.6$ & $10.8 \pm 0.5$ & $<0.001^{*}$ \\
\hline 25-hydroxyvitaminD (nmol/l) & $19.1 \pm 6.3$ & $82.6 \pm 15.8$ & $<0.001^{*}$ \\
\hline *significant & & & \\
\hline
\end{tabular}

Table 2: Comparison between the diabetic children and control group as regard some laboratory parameters.

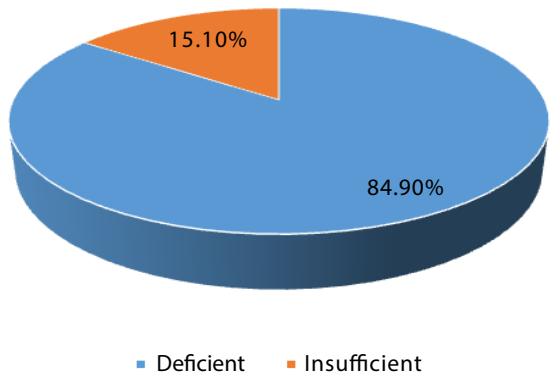

Frequency of low 25-hydroxyvitamin D among the studied diabetic group

Figure 1: Frequency of low 25-hydroxyvitaminD among the studied group.

\begin{tabular}{|c|c|c|c|}
\hline Parameter & $\begin{array}{c}\text { Good } \\
\text { controlled } \\
\text { No=10 }\end{array}$ & $\begin{array}{c}\text { Poor controlled } \\
\text { No }=43\end{array}$ & P- Value \\
\hline $\begin{array}{l}\text { Age:(year) } \\
6-12 . \text { No }(\%) \\
5-10 . \text { No }(\%)\end{array}$ & $\begin{array}{l}2(20 \%) \\
8(80 \%)\end{array}$ & $\begin{array}{l}15(34.9 \%) \\
28(65.1 \%)\end{array}$ & 0.1 \\
\hline $\begin{array}{l}\text { Duration of DM:(years) } \\
\text { 3-5. No }(\%) \\
>5 . \text { No }(\%)\end{array}$ & $\begin{array}{l}8(80 \%) \\
2(20 \%)\end{array}$ & $\begin{array}{c}37(86 \%) \\
6(14 \%)\end{array}$ & 0.6 \\
\hline $\begin{array}{l}\text { Dose of insulin:(IU/kg/day) } \\
\text { (Mean } \pm \text { SD) }\end{array}$ & $0.9 \pm 0.14$ & $0.9 \pm 0.12$ & 0.8 \\
\hline $\begin{array}{l}\text { Type of feeding: } \\
\text { Breast feeding. No (\%) } \\
\text { Artificial milk. No (\%) } \\
\text { Mixed. No (\%) }\end{array}$ & $\begin{array}{c}7(70 \%) \\
0(0 \%) \\
3(30 \%)\end{array}$ & $\begin{array}{c}39(90.7 \%) \\
1(2.3 \%) \\
3(7 \%)\end{array}$ & 0.1 \\
\hline $\begin{array}{l}\text { Family history of DM: } \\
\text { Positive. No (\%) } \\
\text { Negative. No (\%) }\end{array}$ & $\begin{array}{l}2(20 \%) \\
8(80 \%)\end{array}$ & $\begin{array}{c}9(20.9 \%) \\
34(79.1 \%)\end{array}$ & 0.9 \\
\hline $\begin{array}{l}\text { Fasting blood sugar(mg/dl) } \\
\text { (Mean } \pm \text { SD) }\end{array}$ & $121.2 \pm 7.9$ & $259.6 \pm 75.5$ & $<0.001^{\star}$ \\
\hline $\begin{array}{l}\text { Serum calcium level(mg/dl) } \\
\text { (Mean } \pm \text { SD) }\end{array}$ & $8.8 \pm 0.5$ & $8.7 \pm 0.6$ & 0.7 \\
\hline $\begin{array}{l}\text { 25-hydroxyvitaminD (nmol/l): } \\
\text { (Mean } \pm \text { SD) }\end{array}$ & $28.6 \pm 6.5$ & $16.9 \pm 3.7$ & $<0.001^{*}$ \\
\hline
\end{tabular}

*significant

Table 3: Comparison between good and poor glycemic controlled diabetic children as regard some parameters.

that there were significant positive correlations between serum calcium with weight and 25 -hydroxy vitamin $\mathrm{D}$, while there were significant negative correlations between it with height, fasting blood sugar and HbAlc\%. On contrary, there were insignificant correlations between serum calcium with BMI and insulin dose. Furth rely there were significant strong negative correlations between 25-hydroxyvitamin $\mathrm{D}$ and $\mathrm{HbA1c} \%$ and fasting blood sugar where $(\mathrm{r}=-0.7, \mathrm{P}<0.001)$ for each (Table 5$)$. On the other hand, there was a significant strong 


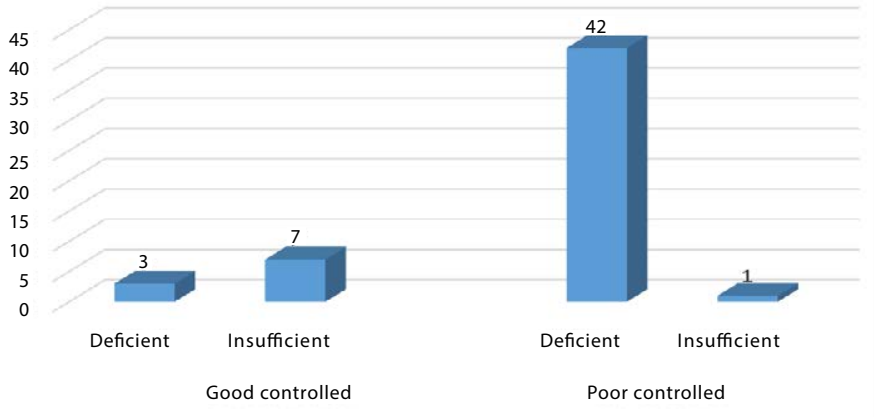

Figure 2: Comparison between good and poor glycemic controlled diabetic children as regard levels of 25-hydroxyvitD whether deficient or insufficient.

\begin{tabular}{|l|c|c|}
\hline \multirow{2}{*}{ Parameter } & \multicolumn{2}{|c|}{ Serum calcium(mg/dl) } \\
\cline { 2 - 3 } & $\mathrm{R}$ & $\mathrm{P}$ \\
\hline Weight (kg) & 0.8 & $<0.001^{*}$ \\
\hline Height (cm) & -0.8 & $<0.001^{*}$ \\
\hline BMI (kg/m $\left.{ }^{2}\right)$ & -0.2 & 0.2 \\
\hline Fasting blood sugar (mg/dl) & -0.5 & $<0.001^{*}$ \\
\hline 25-hydroxyvitamin D (nmol/l) & 0.8 & $<0.001^{*}$ \\
\hline HbA1c (\%) & -0.5 & $<0.001^{*}$ \\
\hline Insulin dose (IU/kg/day) & -0.3 & 0.02 \\
\hline *
\end{tabular}

*significant

Grades of r:0.00 to 0.24 (weak or no association), 0.25 to 0.49 (fair association), 0.50 to 0.74 (moderate association), $\geq 0.75$ (strong association)

Table 4: Correlations between serum calcium and some clinical and laboratory parameters among the diabetic children.

\begin{tabular}{|l|c|c|}
\hline \multirow{2}{*}{ Parameter } & \multicolumn{2}{|c|}{ 25-hydroxyvitamin D } \\
\cline { 2 - 3 } & $\mathbf{R}$ & $\mathbf{P}$ \\
\hline Age(year) & 0.1 & 0.3 \\
\hline Gender & 0.2 & 0.1 \\
\hline Duration of DM(year) & -0.1 & 0.2 \\
\hline Type of feeding & 0.05 & 0.7 \\
\hline Dose of insulin(IU/kg/day) & -0.1 & 0.4 \\
\hline Weight(kg) & 0.2 & 0.2 \\
\hline Height(cm) & 0.1 & 0.5 \\
\hline BMI(kg/m ${ }^{2}$ ) & -0.2 & 0.1 \\
\hline Fasting blood sugar (mg/dl) & -0.7 & $<0.001^{*}$ \\
\hline HbA1c (\%) & -0.7 & $<0.001^{*}$ \\
\hline Serum calcium (mg/dl) & 0.8 & $<0.001^{*}$ \\
\hline
\end{tabular}

Table 5: Correlations between 25-hydroxyvitamin D and some clinical and laboratory parameters.

positive correlation between 25-hydroxyvitamin $\mathrm{D}$ and serum calcium where $(\mathrm{r}=0.8, \mathrm{P}<0.001)$ respectively.

\section{Discussion}

Type 1 diabetes mellitus (T1D) is an autoimmune disease in which the pancreas is unable to respond to secretagogue stimulation with appropriate insulin secretion. Hyperglycemia develops when more than $70-90 \%$ of the insulin-producing beta cells are destroyed. An autoimmune destructive process, which plays a central role in the development of T1D, is facilitated by the subject's own genetic susceptibility and by non-genetic factors. Non-genetic factors include viral infections, toxic chemicals, and others [9].

Vitamin D is a steroid hormone produced in the skin, ha specific regulatory or functional effects on other parts of the body. Vitamin $\mathrm{D}$ is hydroxylated in the liver to 25-hydroxyvitamin $\mathrm{D}(25[\mathrm{OH}] \mathrm{D})$ and further hydroxylated in the kidney to 1,25-dihydroxyvitamin D. Hydroxylation in the kidney is regulated closely by parathyroid hormone (PTH), hypocalcaemia, and hypo-phosphatemia and is inhibited by 1,25-dihydroxyvitamin D [10]. Nutritional status with respect to vitamin $\mathrm{D}$ is best represented by the circulating concentration of plasma 25-hydroxyvitD [11].

The aim of our study was to evaluate vitamin D status in children with T1D and to correlate it with different clinical and laboratory parameters.

As regard the results of the current study, comparison between the diabetic children and the control group as regards some clinical parameters showed that group I had higher weight and shorter height than group II (Table 1). This result was in agreement with Thon et al. [12] and Paulino et al. [13] who found that diabetic children were higher in weight and shorter in comparison to healthy children. Concerning BMI and waist circumference, there were insignificant difference between group I and group II where $\mathrm{P}>0.05$. This result was in agreement with Mao et al. [14]. Regarding some laboratory parameters, Table 2 showed that group I had significant higher fasting blood sugar and $\mathrm{HbA1c} \%$ than group II. This was in agreement with Paul et al. [15].

On the other hand, group I had significant lower serum calcium level than group II. This could be explained by that diabetic children had osmotic diuresis with glycosuria with subsequent increase of renal excretion of calcium (Hypercalciuria) which leads to reduction of serum calcium than the normal and good controlled patients [16].

Concerning 25-hydroxyvitamin D, group I had significantly lower serum level than group II where $\mathrm{P}<0.001$. This could be explained by that Vitamin $\mathrm{D}$ deficiency may promote beta cells destruction in humans. Moreover, the presence of T1D is related to low vitamin D concentration whilst the lowering of 25-hydroxyvi tD levels during the years after diagnosis is a consequence of disturbed metabolism due to diabetes mellitus. Indeed, this may be explained why bone density is lower in T1D than in T2D [17]. In animal (mice) study, a vitamin $\mathrm{D}$ analogue had been shown to down regulate the production of proinflammatory chemokines, thereby inhibiting T-cell recruitment and the development of T1D [18].

Another possible mechanism is that vitamin D may have direct effects on B-cells, including improving insulin secretion, enhancing expression of vitamin D receptors and improving islet morphology [13]. This result was in agreement with Littorin et al. [19] who found that 25-hydroxyvitD was lower in patients with T1DM compared with control subjects whether they are recently diagnosed or after years of diagnosis. This finding may support the idea that vitamin $\mathrm{D}$ deficiency may be an important factor behind the development of T1D, perhaps with an immunological background [20-24]. Also, it was lower after years of diagnosis of T1D and this was in agreement with Svoren et al. [25] and Bin-Abbas et al. [26].

Figure 1 showed that $15.1 \%$ of T1D patients were 25 -hydroxyvitD insufficient and $84.9 \%$ were deficient. In comparison to our result, Bener et al. [27] found $90.6 \%$ of diabetics versus $85.3 \%$ of nondiabetics had vitamin D deficiency and in northeastern US, it had been found that $15 \%$ of T1D were 25 -hydroxyvitD deficient versus $61 \%$ insufficient [28]. Furthermore, Janner et al. [29], found $60.5 \%$ of diabetic children were vitamin D deficient. Similarly, in North India, in a case-control study, $58 \%$ of T1D versus $32 \%$ of the control [30]. 
Recently, Piccini et al. [31] found that vitamin D deficiency was present in $43.9 \%$ of patients and insufficiency in $35.5 \%$ according to studies conducted on healthy children. Furthermore, Branco et al. [32] found that there was insufficiency in $28 \%$ of T1DM patients, deficiency in $32 \%$, severe deficiency in $9 \%$ and normal in $31 \%, 55 \%$ deficiency of boys and $45 \%$ of girls. Concerning glycemic control, Table 3 showed that good glycemic controlled children had insignificant difference than poor glycemic controlled children as regard age and duration of DM. This was in agreement with Hartmann et al. [33]. As regard the dose of insulin, there was insignificant difference between good and poor glycemic controlled patients where $(\mathrm{P}=0.3)$. This was in agreement with Reinhard et al. [34] who found that metabolic control was unsatisfactory in many patients with T1D irrespective of the insulin regimen. Regarding the type of feeding, the current study found insignificant difference between good and poor glycemic controlled children where $(\mathrm{P}=0.1)$. This finding was in contrary to the finding by Hana et al. [35]. Concerning family history of DM, there was insignificant difference between good and poor glycemic controlled children where $(\mathrm{P}=0.9)$ (Table 4$)$. This was in contrary to Lucy et al. [36] who found that a higher familial risk of diabetes had a worse glycemic control. Furthermore, this was in contrary to Kuo et al. [37] who found that positive paternal history was associated with worse glycemic control.

As regard calcium levels, there was insignificant difference between good and poor glycemic controlled children where $(\mathrm{P}=0.7)$. This was in agreement with Alberto et al. [38] while others such as Duarte et al. [39], Blasiak et al. [40] found significant difference between good and poor glycemic controlled children

Concerning 25-hydroxy vitD, good glycemic controlled children had significant higher levels than poor glycemic controlled children where $(\mathrm{P}<0.001)$.

Concerning different correlations, Table 4 showed that there were significant correlations between serum calcium and weight, height, fasting blood sugar, 25-hydroxyvitD and $\mathrm{HbA1C} \%$ where $(\mathrm{P}<0.001)$. In contrary, there were insignificant correlations between calcium with BMI and insulin dose.

Table 5 showed that there were significant strong negative correlations between 25-hydroxyvitD and fasting blood sugar, HbAlc $\%$ where $(\mathrm{r}=-0.7, \mathrm{P}<0.001)$ respectively. In contrast, Littorin et al. [19] found that there was insignificant correlation between 25-hydroxy vit $\mathrm{D}$ levels and $\mathrm{HbA} 1 \mathrm{c} \%$ and this indicated that the diabetic state per say is a reason for low 25-hydroxyvitD levels and is not secondary to any hyperglycemic or insulin-resistant state. On the other hand, there was a significant strong positive correlation between 25-hydroxyvitD and serum calcium where $(\mathrm{r}=0.8, \mathrm{P}<0.001)$ respectively.

\section{Recommendations}

Screening for vitamin D deficiency, insufficiency and supplementation in children with T1D and groups at risk for this disease. There is a need to increase the dose of vitamin D supplemented to diabetic children to avoid many complications. Follow up studies of supplemented diabetic children with vitamin D deficiency and evaluation of their glycemic control.

\section{References}

1. Thnc O, Cetinkaya S, Kizilgün M, Aycan Z (2011) Vitamin D status and insulin requirements in children and adolescent with type 1 diabetes. $J$ Pediatr Endocrinol Metab 24: 1037-1041.

2. American Diabetes Association (2013) Diagnosis and classification of Diabetes Mellitus. Diabetes Care 36: 72
3. Nathan DM, Singer DE, Hurxthal K, Goodson JD (1984) The clinical information value of the glycosylated hemoglobin assay. N Engl J Med 310: 341-346.

4. Gindler EM, King JD (1972) Rapid colorimetric determination of calcium in biologic fluids with methylthymol blue. Am J Clin Pathol 58: 376-382.

5. Scharla SH, Scheidt-Nave C, Leidig G, Woitge H, Wüster C, et al.(1996) Lower serum 25-hydroxyvitamin $D$ is associated with increased bone resorption markers and lower bone density at the proximal femur in normal females: a population-based study. Exp Clin Endocrinol Diabetes.104: 289-292.

6. Scharla SH (1998) Prevalence of subclinical vitamin D deficiency in different European countries. Osteoporos Int 8 Suppl 2: S7-12.

7. Thacher TD, Clarke BL (2011) Vitamin D insufficiency. Mayo Clin Proc 86: 5060.

8. Daniel W (1999) Biostatistics: A Foundation for Analysis in the Health Sciences ( $7^{\text {th }}$ edtn). New York: John wiley and sons.944.

9. Agustin B, Bianca A and Leonid O (2011) INTECH; Medicine, Endocrinology and Metabolism, Role of Vitamin D in the Pathogenesis and Therapy of Type Diabetes Mellitus, type 1 diabetes complications, pathogenesis and alternative treatments. 19: 403 .

10. Lips P (2006) Vitamin D physiology. Prog Biophys Mol Biol 92: 4-8.

11. Zerwekh JE (2004) The measurement of vitamin D: analytical aspects. Ann Clin Biochem 41: 272-281.

12. Thon A, Heinze E, Feilen KD, Holl RW, Schmidt H, et al. (1992) Development of height and weight in children with diabetes mellitus: report on two prospective multicentre studies, one cross-sectional, one longitudinal. Eur J Pediatr 151 258-262.

13. Paulino MF, de Lemos-Marini SH, Guerra-Júnior G, Minicucci WJ, Mendes CT, et al. (2006) Growth and body composition in children with type 1 diabetes mellitus. Arq Bras Endocrinol Metabol 50: 490-498.

14. Mao L, Lu W, Ji F, Lv S (2011) Development and linear growth in diabetic children receiving insulin pigment. J Pediatr Endocrinol Metab 24: 433-436.

15. Ciechanowski PS, Hirsch IB, Katon WJ (2002) Interpersonal predictors of $\mathrm{HbA}(1 \mathrm{c})$ in patients with type 1 diabetes. Diabetes Care 25: 731-736.

16. Raskin P, Unger RH (1978) Hyperglucagonemia and its suppression Importance in the metabolic control of diabetes. N Engl J Med 299: 433-436.

17. Petrova NL, Foster AV, Edmonds ME (2005) Calcaneal bone mineral density in patients with Charcot neuropathic osteoarthropathy: differences between Type 1 and Type 2 diabetes. Diabet Med 22: 756-761.

18. Giarratana N, Penna G, Amuchastegui S, Mariani R, Daniel KC, et al. (2004) Vitamin $D$ analog down-regulates proinflammatory chemokine production by pancreatic islets inhibiting T cell recruitment and type 1 diabetes development. J Immunol 173: 2280-7.

19. Littorin B, Blom P, Schölin A, Arnqvist HJ, Blohmé G, et al. (2006) Lower levels of plasma 25-hydroxyvitamin $D$ among young adults at diagnosis of autoimmune type 1 diabetes compared with control subjects: results from the nationwide Diabetes Incidence Study in Sweden (DISS). Diabetologica 49: 2847-52.

20. Szanya V, Ermann J, Taylor C, Holness C, Fathman CG (2002) The subpopulation of CD4+CD25+ splenocytes that delays adoptive transfer of diabetes expresses L-selectin and high levels of CCR7. J Immunol 169: 2461 2465.

21. Fronczak CM, Barón AE, Chase HP, Ross C, Brady HL, et al. (2003) In utero dietary exposures and risk of islet autoimmunity in children. Diabetes Care 26 3237-3242.

22. Zella JB, DeLuca HF (2003) Vitamin D and autoimmune diabetes. J Cell Biochem 88: 216-222.

23. Kim SH, Cleary MM, Fox HS, Chantry D, Sarvetnick N (2002) CCR4-bearing T cells participate in autoimmune diabetes. J Clin Invest 110: 1675-1686.

24. Zemunik T, Skrabic V, Boraska V, Diklic D, Terzic IM, et al. (2005) Fok polymorphism, vitamin $\mathrm{D}$ receptor, and interleukin-1 receptor haplotypes are associated with type 1 diabetes in the Dalmatian population. J Mol Diagn 7 : $600-604$.

25. Svoren BM, Volkening LK, Wood JR, Laffel LM (2009) Significant vitamin deficiency in youth with type 1 diabetes mellitus. J Pediatr 154: 132-134. 
Citation: Soliman GT, Ali BA, Mohamed AA, Mahmoud AM, Abdellatif AA (2015) Assessment of Vitamin D Status in Egyptian Children with Type-1 Diabetes Mellitus. J Diabetes Metab 6: 573. doi:10.4172/2155-6156.1000573

Page 5 of 5

26. Bin-Abbas BS, Jabari MA, Issa SD, Al-Fares AH, Al-Muhsen S (2011) Vitamin D levels in Saudi children with type 1 diabetes. Saudi Med J 32: 589-592.

27. Bener A, Alsaied A, Al-Ali M, Al-Kubaisi A, Basha B, et al. (2009) High prevalence of vitamin $D$ deficiency in type 1 diabetes mellitus and healthy children. Acta Diabetol 46: 183-189.

28. Svoren BM, Butler D, Levine BS, Anderson BJ, Laffel LM (2003) Reducing acute adverse outcomes in youths with type 1 diabetes: a randomized, controlled trial. Pediatrics 112: 914-922.

29. Janner M, Ballinari $P$, Mullis PE, Flück CE (2010) High prevalence of vitamin D deficiency in children and adolescents with type 1 diabetes. Swiss Med Wkly 140: w13091.

30. Borkar VV, Devidayal, Verma S, Bhalla AK (2010) Low levels of vitamin D in North Indian children with newly diagnosed type 1 diabetes. Pediatr Diabetes 11: $345-350$.

31. Piccini A, Barni F, Gausti M, Lenzi L, Ricci F, et al. (2012) Vitamin D levels in youth with type 1 diabetes:effects of vitamin $D$ supplementation on glycemic control. Pediatric Diabetes 13: 48.

32. Branco S, Rego C, Costa C (2012) Vitamin D deficiency in children and adolescents with type 1 diabetes. Pediatric Diabetes 13: 91-2.

33. Hartemann-Heurtier A, Sultan S, Sachon C, Bosquet F, Grimaldi A (2001) How type 1 diabetic patients with good or poor glycemic control cope with diabetesrelated stress. Diabetes Metab 27: 553-559.
34. Reinhard W. Holl, Peter G. Swift, Henrik B. Mortensen (2003) Insulin injection regimens and metabolic control in an international survey of adolescents with type 1 diabetes over 3 years: results from the Hvidore study group. European Journal of Pediatrics 162: 22-9.

35. Malcova H, Sumnik Z, Drevinek P, Venhacova J, Lebl J, et al. (2006) Absence of breast-feeding is associated with the risk of type 1 diabetes: a case-control study in a population with rapidly increasing incidence. Eur J Pediatr 165: 114119

36. Lucy Gong, Wen Hong Linda Kao, Frederick L. Brancati, Marian Batts-Turner, Tiffany L. Gary (2008) Association Between Parental History of Type 2 Diabetes and Glycemic Control in Urban African Americans. Diabetes Care 31: 1773-6.

37. Kuo CK, Lin LY, Yu YH, Chang CH, Kuo HK (2010) A family history of diabetes mellitus is associated with poor glycemic control and increased metabolic risks among people with diabetes: data from the National Health and Nutrition Examination Survey 1999-2004. Intern Med. 49: 549-55.

38. Verrotti A, Blasetti A, Tumini S, Chiarelli F, Morgese G (1988) Calcium homeostasis in prepubertal diabetic children. Acta Diabetol Lat 25: 173-177.

39. Duarte VM, Ramos AM, Rezende LA, Macedo UB, Brandão-Neto J, et al (2005) Osteopenia: a bone disorder associated with diabetes mellitus. J Bone Miner Metab 23: 58-68.

40. BÅ,asiak M, Kuska J, Kokot F, Irzyniec T (1989) Selected indicators of calciumphosphate metabolism in patients with diabetes mellitus. Endokrynol Pol 40: 251-262. 